\title{
KADAR AIR, pH, DAN KAPANG IKAN CAKALANG (Katsuwonus pelamis) ASAP CAIR YANG DIKEMAS VAKUM DAN NON VAKUM PADA PENYIMPANAN DINGIN
}

\author{
Zulviki Alinti $^{1}$, Semuel M. Timbowo ${ }^{2}$, Feny Mentang ${ }^{2}$ \\ ${ }^{1)}$ Mahasiswa pada Program Studi Teknologi Hasil Perikanan FPIK Unsrat Manado \\ ${ }^{2)}$ Staf pengajar pada Program Studi Teknologi Hasil Perikanan FPIK Unsrat Manado
}

\begin{abstract}
Fish is one food that is not foreign to the Indonesian community, this food has advantages that contain essential amino acids needed by the body, in addition to the biological reaches $90 \%$ with the network binder is easily digested, but it is much cheaper price. Compare other protein sources. Fish is also one of the ingredients that are easily damaged or deteriorated in quality. One of the fish processing that is done by fumigation, Fogging is a way of processing or preservation by utilizing a combination of natural control and testing of natural fuel goods such as liquid smoke. One of the proper ways to maintain the durability of skipjack (Katsuwonus pelamis L. asap) is by packing a vacuum. The main principle of vacuum packaging is the specific output of $\mathrm{O}_{2}$ from the product so as to support the shelf life. Further modified with cold storage for better results. This study aims to overcome the deterioration of tuna liquid quality stored for 0,7 and 21 days, stored at cold temperature $\left( \pm 5^{\circ} \mathrm{C}\right)$ packed vacuum and non vacuum with $\mathrm{pH}$ quality test, moisture content and shell. The research method used is an experimental method of revision of facts based on existing problems through hypotheses. Of the 3 test parameters, the results generated during the study are; Results of water in the lowest vacuum packed liquid $(58.8 \%)$ of skim milk $(57 \%)$ in non-vacuum packed liquid smoke fish; The highest pH value was 5.885 on the conventional tuna and the lowest was 5.77 in the vacuum liquid tuna; The highest total colonies of $3.9 \times 10^{3}$ in the vacuum packed liquid skipjack and the lowest $<10$ in the skipjack.
\end{abstract}

Keyword: Water content, pH, Fungi, Skipjack tuna, Katsuwonus Pelamis, Liquid Smoke, Packed Vacuum and Non Vacuum, Cold Storage.

\begin{abstract}
ABSTRAK
Ikan merupakan salah satu bahan makanan yang tidak asing lagi bagi masyarakat Indonesia, bahan makanan ini memiliki kelebihan yaitu mengandung asam amino essensial yang diperlukan oleh tubuh, disamping itu nilai biologisnya mencapai 90\% dengan jaringan pengikat sedikit sehingga mudah dicerna, selain itu harganya jauh lebih murah dibandingkan sumber protein lainnya. Ikan juga merupakan salah satu bahan makanan yang mudah rusak atau mengalami kemunduran mutu. Salah satu pengolahan ikan yang dilakukan yaitu dengan cara pengasapan, Pengasapan merupakan cara pengolahan atau pengawetan dengan memanfaatkan kombinasi perlakuan pengeringan dan pemberian senyawa kimia alami dari hasil pembakaran bahan bakar alami seperti asap cair. Salah satu cara yang tepat untuk mempertahankan daya awet ikan cakalang (Katsuwonus pelamis L. asap ) yaitu dengan dikemas vakum. Prinsip utama dari pengemasan vakum adalah pengeluaran khususnya $\mathrm{O}_{2}$ dari produk sehingga dapat memperpanjang masa simpan. Selanjutnya dimodifikasi dengan penyimpanan dingin untuk memperoleh hasil yang lebih baik. Penelitian ini bertujuan untuk mengamati kemunduran mutu ikan cakalang asap cair yang disimpan selama 0 hari, 7 hari dan 21 hari, disimpan pada suhu dingin $\left( \pm 5^{\circ} \mathrm{C}\right.$ ) yang dikemas vakum dan non vakum dengan pengujian mutu meliputi $\mathrm{pH}$, Kadar Air dan Kapang. Metode penelitian yang digunakan adalah metode eksperimen eksploratif yaitu mengungkapkan fakta-fakta berdasarkan problema yang ada melalui hipotesa. Dari 3 parameter pengujian, hasil yang diperoleh selama penelitian yaitu; diperoleh nilai kadar air tertinggi pada ikan cakalang asap cair yang dikemas vakum $(58,8 \%)$ terendah $(57 \%)$ pada ikan cakalang asap cair yang tidak dikemas vakum; nilai pH tertinggi 5,885 pada ikan cakalang asap konvensional dan terendah 5,77 pada ikan cakalang asap cair vakum; nilai total koloni kapang tertinggi $3,9 \times 10^{3}$ pada ikan cakalang asap cair yang dikemas vakum dan terendah $<10$ pada ikan cakalang konvensional.
\end{abstract}

Kata Kunci: Kadar Air, pH, Kapang, Cakalang, Asap Cair, Katsuwonus Pelamis, Kemasan Vakum, Kemasan Non Vakum, Penyimpanan Dingin.

\section{PENDAHULUAN}

Ikan merupakan salah satu bahan makanan yang tidak asing lagi bagi masyarakat
Indonesia, bahan makanan ini memiliki kelebihan yaitu mengandung asam amino essensial yang diperlukan oleh tubuh, disamping itu nilai 
biologisnya mencapai $90 \%$ dengan jaringan pengikat sedikit sehingga mudah dicerna, selain itu harganya jauh lebih murah dibandingkan sumber protein lainnya (Adawyah, 2007).

Ikan merupakan salah satu bahan makanan yang mudah mengalami kemunduran mutu. Kemunduran mutu ikan disebabkan oleh aksi enzimatis dan aksi bakteri. Kedua aksi ini menguraikan komponen penyusun jaringan tubuh ikan sehingga menghasilkan perubahan fisik seperti daging ikan menjadi lunak dan perubahan kimia yang menghasilkan senyawa mudah menguap dan berbau busuk (Murniati, 2000).

Salah satu penyebab terjadinya kemunduran mutu ikan asap yaitu kadar air. (Agus, et al. 2014) menyatakan bahwa kadar air merupakan parameter yang penting untuk menentukan kualitas ikan asap yang dihasilkan. Kadar air yang terkandung dalam ikan asap dapat mempengaruhi daya simpan ikan asap. Karena kadar air merupakan media mikroba untuk berkembang biak. Menurut Buckle et al. (1987) bahwa pengaruh kadar air sangat penting sekali dalam menentukan daya awet suatu bahan pangan karena kadar air mempengaruhi sifat-sifat fisik (organoleptik), sifat kimia dan kebusukan oleh mikroorganisme.

Nilai $\mathrm{pH}$ juga merupakan salah satu indikator yang digunakan untuk menentukan tingkat kesegaran ikan. Pada proses pembusukan ikan, perubahan $\mathrm{pH}$ daging sangat besar peranannya karena berpengaruh terhadap proses autolysis dan penyerangan bakteri. Menurut Fardiaz (1982) $\mathrm{pH}$ yang baik untuk ikan yang diawetkan antara 2,0-5,5 sedangkan $\mathrm{pH}$ antara 6,0-8,0 merupakan media yang baik untuk pertumbuhan mikroorganisme.

Hal lain juga yang menjadi indikator penentu mutu dari ikan asap adalah kapang. Keberadaannya berpengaruh bagi mutu dan keamanan dari produk pangan karena ada jenis tertentu yang memproduksi mikotoksin (Sopandi dan Wardah, 2013). Kapang merupakan organisme eukaryotik ber sel banyak, dengan ukuran sel berkisar 20-100 $\mathrm{mm}$. Organisme ini termasuk tidak bergerak, berfilamen dan bercabang. Talusnya terdiri dari sejumlah filament yang disebut hifa yang tersusun dalam sebuah kumpulan terbentuk agregat yang disebut meselium (Sopandi dan Wardah, 2013). Reproduksi hifa dilakukan dengan perpanjangan hifa udara dan ekspora, konidia atau ekspora dalam kantung (Sporagium). Ukuran, bentuk dan warna spora, menjadi dasar untuk klasifikasinya (Ray, 2004).
Salah satu jenis pengolahan yang dapat digunakan untuk menghambat kegiatan zat-zat mikroorganisme adalah pengasapan ikan, selain bertujuan memberikan manfaat untuk mengawetkan ikan pengolahan ikan dengan cara pengasapan juga memberi aroma yang sedap, warna kecoklatan atau kehitaman, tekstur yang bagus serta cita rasa yang khas dan lezat pada daging ikan yang diolah (Wibowo, 1996).

Saat ini, asap cair telah banyak digunakan oleh industri pangan sebagai bahan pemberi aroma, tekstur dan citarasa yang khas pada produk pangan, seperti daging, ikan, dan keju (Soldera et al. 2008). Di Indonesia, asap cair sudah digunakan oleh industri pembuatan bandeng asap di Sidoarjo (Hadiwiyoto et al. 2000). Penggunaan asap cair tempurung kelapa pada skala laboratorium juga cukup banyak dilakukan. Hasil penelitian Haras (2004) menyebutkan bahwa ikan cakalang yang direndam dalam asap cair tempurung kelapa $2 \%$ selama 15 menit dan disimpan pada suhu kamar mulai mengalami kemunduran mutu pada hari ke-4. Pencelupan atau perendaman dapat menghasilkan mutu organ oleptik yang tinggi terutama pada hasil produk olahan daging pada bagian bahu dan perut, sosis dan keju itali (Martinez et al. 2007).

\section{METODOLOGI PENELITIAN}

\section{Tempat dan Waktu Penelitian}

Penelitian ini dilaksanakan di Laboratorium Penanganan dan Pengendalian Mutu Hasil Perikanan, Fakultas Perikanan dan Ilmu Kelautan Universitas Sam Ratulangi Manado. Waktu yang dibutuhkan untuk penelitian, mulai dari penyusunan rencana kerja penelitian sampai penulisan Skripsi memerlukan waktu 4 bulan yang diperkirakan mulai bulan Februari sampai dengan Juni 2017.

\section{Alat dan Bahan}

Ikan Cakalang (Katsuwonus pelamis) yang akan di filet, tempurung kelapa $20 \mathrm{~kg}$ yang akan digunakan sebagai bahan pembuatan asap cair dan es. Bahan Kimia yang digunakan untuk pengujian yaitu; PDA, Akuades, $\mathrm{NaCl}$, Indikator $\mathrm{pH}$.

Alat pembuatan asap cair tungku pembakaran, toples, kompor, oven, pisau, keranjang, talenan, lemari pendingin untuk tempat penyimpanan sampel dengan kisaran suhu 4$5^{\circ} \mathrm{C}$, cool box. Alat untuk pengujian: autoclave, tabung reaksi, cawan porselen, mortar, blender, 
erlemeyer, pipet, cawan petri, inkubator, desikator termometer timbangan, $\mathrm{pH}$ meter, tisu, lampu spritus.

\section{Prosedur Penelitian}

Metode penelitian yang digunakan adalah metode eksperimen eksploratif yaitu mengungkapkan fakta-fakta berdasarkan problema yang ada melalui hipotesa. Menurut Hadi (1970), penelitian eksperimen eksploratif adalah penjelajahan yang bermaksud mencari problema-problema atau pengembangan hipotesa tentang hubungan sebab akibat atau gejala.

\section{Tata Laksana Penelitian}

Tata laksana penelitian sebagai berikut:

1. Sampel yang digunakan dalam penelitian ini adalah ikan Cakalang asap cair yang dibuat di Laboratorium Pengendalian Mutu Hasil Perikanan untuk perlakuan selanjutnya.

2. Kemudian sampel dibagi menjadi 2 bagian masing-masing dikemas vakum dan non vakum dan disimpan pada suhu dingin $\left( \pm 5^{\circ} \mathrm{C}\right)$ selama 21 hari.

3. Analisa yang dilakukan meliputi pengujian kadar air, $\mathrm{pH}$ dan pengujian kapang. pengujian dilakukan secara bersamaan untuk 3 parameter uji.

4. Pengujian kadar air, $\mathrm{pH}$ dan kapang dilakukan dengan 2 kali ulangan untuk setiap perlakuan penyimpanan.

\section{Pembuatan Asap Cair}

Tempurung kelapa yang sudah kering dibersihkan dari kotoran yang menempel kemudian ditimbang dengan barat $15 \mathrm{~kg}$. Kemudian dimasukan pada tungku pembakaran untuk menghasilkan asap, asap hasil pembakaran dialirkan pada pipa-pipa besi berdiameter 7,5 yang telah disambungkan ke tangki pembakaran, kemudian asap hasil pembakaran dialirkan lagi ke pipa paralon yang berdia meter $8 \mathrm{~cm}$. asap yang terdapat pada pipa kemudian didinginkan dengan mengunakan media pendingin es sebanyak 7 balok, dimana terjadi proses kondensasi dimana asap akan beruba menjadi cairan. Asap yang telah terbentuk ditampung pada wadah seperti toples yang di pasang pada ujung pipa.

\section{Pembuatan Konsentrasi Asap Cair (Pagorai,} 2004)

1. Erlenmeyer dicuci bersih, kemudian dikeringkan dalam oven pada suhu $105^{\circ} \mathrm{C}$ selama satu malam sampai beratnya konstan.
2. Kemudian erlenmeyer dimasukan ke dalam desikator selama 30 menit, lalu ditimbang.

3. Asap cair sebanyak $10 \mathrm{ml}$ dimasukan ke dalam erlenmeyer, kemudian dikeringkan dalam oven pada suhu $105^{\circ} \mathrm{C}$ sampai beratnya konstan.

4. Kemudian masukan erlenmeyer tersebut ke dalam desikator selama 30 menit, setelah itu ditimbang. Konsentrasi asap cair dapat dihitung dengan rumus:

$\frac{\text { (Berat erlenmeyer+sampel akhir)-berat erlenmeyer awal }}{\text { (Berat erlenmeyer+sampel awal)-berat erlenmeyer awal }} \times 100$

\section{Parameter Yang Diuji}

Parameter yang diuji adalah pengujian kadar air, pH dan kapang.

\section{Analisa Uji Kadar Air (AOAC, 1995)}

Analisis kadar air dengan menggunakan oven. Kadar air dihitung sebagai persen berat, artinya berapa gram berat contoh dengan yang selisih berat dari contoh yang belum diuapkan dengan contoh yang telah dikeringkan. Jadi kadar air dapat diperoleh dengan menghitung kehilangan berat contoh yang dipanaskan, urutan kerjanya sebagai berikut:

- Cawan porselen dengan penutup dibersihkan dan dikeringkan dalam oven pada suhu $105-110^{\circ} \mathrm{C}$ selama $1 \mathrm{jam}$. Kemudian didinginkan dalam desikator selama 30 menit dan ditimbang beratnya (A gram).

- Sampel ditimbang sebanyak 2 gram dan ditaruh dalam cawan porselen yang telah diketahui beratnya (B gram). Sampel dalam porselen ini kemudian dikeringkan dalam oven pada suhu $105-110^{\circ} \mathrm{C}$ sampel konstan selama 24 jam, selanjutnya didinginkan dalam desikator selama 30 menit dan ditimbang ( $\mathrm{C}$ gram).

- Penimbangan ini di ulang sampai diperoleh berat yang konstan.

Adapun presentase kadar air yang dapat dihitung sebagai berikut:

$$
\text { Kadar air }=\frac{(B-C)}{(B-A)} \times 100 \%
$$

\section{Penentuan Nilai pH}

Menurut Suwetja, dkk. (2007), bahwa penentuan $\mathrm{pH}$ dapat dilakukan dengan menggunakan $\mathrm{pH}$ meter, dengan urutan kerja sebagai berikut:

1. Timbang sampel yang telah dirajang kecilkecil sebanyak $10 \mathrm{~g}$ dihomogenkan menggunakan mortar dengan $20 \mathrm{ml}$ akuades selama 1 menit. 
2. Tuangkan ke dalam beker glass $10 \mathrm{ml}$, kemudian diukur pH-nya dengan menggunakan $\mathrm{pH}$ meter.

3. Sebelum $\mathrm{pH}$ meter digunakan, harus ditera kepekaan jarum penunjuk dengan larutan buffer $\mathrm{pH} 7$.

4. Besarnya $\mathrm{pH}$ adalah pembacaan jarum penunjuk $\mathrm{pH}$ setelah jarum skala konstan kedudukannya.

\section{Analisa Total Koloni Kapang (Modifikasi Fardiaz, $d k k$. 1993)}

berikut:

Prosedur total koloni kapang sebagai

1. Semua peralatan yang akan digunakan dalam analisa mikrobiologi disterilkan dengan menggunakan autoklaf pada suhu $121^{\circ} \mathrm{C}$ selama 15 menit dengan tekanan 15 psi.

2. PDA disiapkan sebagai berikut: sejumlah 3,9 gram Potato Dextro Agar (PDA) ditambahkan pada $100 \mathrm{ml}$ akuades kemudian didihkan. Setelah itu disterilkan dalam autoklaf pada suhu $121^{\circ} \mathrm{C}$ selama 15 menit dengan tekanan 15 psi.

3. Siapkan tabung reaksi yang diberi kode IIII yang berisi masing-masing $9 \mathrm{ml} \mathrm{NaCl}$ $0,9 \%$ kemudian disterilkan.

4. Sampel diblender sampai halus, kemudian ditimbang sebanyak 10 gram dan dimasukkan ke dalam erlenmeyer $250 \mathrm{ml}$ berisi 90 ml larutan $\mathrm{NaCl}$ 0,9 \% steril. Sampel ini merupakan pengenceran $10^{-1}$.

5. Kemudian dari larutan tersebut diambil $1 \mathrm{ml}$ dan dipindahkan ke tabung reaksi I dengan cara dipipet untuk mendapatkan pengenceran $10^{-2}$. Dari tabung reaksi I dipipet lagi $1 \mathrm{ml}$ dan dipindahkan ke tabung reaksi ke II sebagai pengenceran $10^{-3}$, demikian seterusnya sampai tabung ke III yang merupakan pengenceran $10^{-4}$.

6. Dari setiap pengenceran diambil masingmasing $1 \mathrm{ml}$ larutan secara aceptik dimasukkan dalam dua cawan Petri steril.

7. Selanjutnya masukkan PDA steril (suhu 43$46^{\circ} \mathrm{C}$ ) sebanyak $\pm 15 \mathrm{ml}$, ke dalam cawan petri lalu dihomogenkan dengan cara digoyang ke kiri, ke kanan, ke belakang dan dibiarkan sampai membeku. Setelah media membeku, petri disusun terbalik dalam inkubator bersuhu $25-30^{\circ} \mathrm{C}$ dan diinkubasi selama 24-48 jam.

8. Kemudian dihitung jumlah koloni kapang yang tumbuh pada media agar di cawan petri. Koloni yang dihitung berjumlah 30
300 koloni. Jumlah total koloni kapang yang dihitung, kemudian dikalikan dengan faktor pengenceran.

\section{Analisa Data}

Data yang diperoleh dibedakan menjadi 2 kategori yaitu data kualitatif dan data kuantitatif. Data kualitatif dilakukan cukup dengan menghubungkan makna dari ke dua data uji yang dilakukan. Data kuantitatif adalah data dalam bentuk tabel-tabel, dan grafik. Data untuk uji kadar air, $\mathrm{pH}$ dan Kapang yang diperoleh, ditentukan ditabulasi dengan mencari nilai rata-rata kemudian disajikan dalam bentuk tabel dan grafik. Data dari hasil pengujian laboratorium dipaparkan secara deskriptif. Selanjutnya hasil tersebut dikaji dan dibandingkan dengan persyaratan mutu ikan cakalang asap.

\section{HASIL DAN PEMBAHASAN}

\section{Kadar Air}

Berdasarkan hasil penelitian, diperoleh nilai rata-rata kadar air ikan cakalang asap cair selama penyimpanan pada pengemas vakum dan non vakum. Nilai rata-rata kadar air ikan asap cair ini pada penyimpanan 0 hari pada produk yang dikemas vakum adalah $58,5 \%$ dan pada produk yang tidak dikemas vakum adalah $58 \%$ sedangkan pada ikan cakalang konvensional yang tidak dikemas vakum adalah 58,2\%. Pada penyimpanan 7 hari nilai rata-rata kadar air pada produk yang dikemas vakum adalah 58,55\% dan yang tidak dikemas vakum adalah $57,35 \%$ sedangkan pada ikan asap konvensional adalah $57,45 \%$. Pada penyimpanan 21 hari nilai ratarata kadar air pada produk yang dikemas vakum adalah $58,8 \%$ dan yang tidak dikemas vakum adalah $57 \%$ sedangkan pada ikan asap konvensional adalah 557,2\%. Dari data tersebut dapat dibuat suatu hubungan antara lama penyimpanan terhadap kadar air ikan asap yang dikemas vakum dan non vakum. Hubungan tersebut dapat dilihat pada gambar 1 .

Dari gambar 1 menunjukkan nilai kadar air sampel ikan cakalang asap cair yang dikemas vakum mengalami kenaikan kadar airnya, sedangkan pada ikan asap cair yang tidak dikemas vakum dan ikan asap konvensional mengalami penurunan. Pada produk yang dikemas vakum dapat berpengaruh kurang baik untuk menurunkan dan mempertahankan kadar air karena kadar air dalam produk mengalami peningkatan selama penyimpanan. Peningkatan kadar air pada produk kemungkinan disebabkan oleh terse- 
rapnya uap air yang ada di lingkungan sekitar meskipun telah dikemas dengan bahan pengemas plastik, mengingat karena plastik memiliki sifat permeabel terhadap uap air maka akan memudahkan uap air dapat masuk (terserap) ke dalam ikan. Hal ini karena adanya perbedaan tekanan di dalam dan di luar kemasan akan mengakibatkan masuknya uap air ke dalam kemasan dan uap air tersebut diserap oleh produk sehingga menaikkan kadar air produk selama penyimpanan (Ishak dan Amrullah, 1984). Tingginya kadar air pada produk yang dikemas sehingga menyebabkan tingginya kelembaban dalam plastik sebagai pengemas dan menyebabkan mikroba dapat tumbuh dengan cepat. Dapat dilihat juga pada produk ikan asap cair yang tidak dikemas vakum dan juga ikan asap konvensional terjadi penurunan nilai kadar air seiring lamanya penyimpanan, penurunan kadar air ini kemungkinan disebabkan terjadinya penguapan dari produk karena pengaruh dari suhu dan kelembaban sekitar yang lebih rendah dari pada kelembaban produk. Winarno (1980), menyatakan bahwa kadar air suatu produk dipengaruhi oleh kelembaban udara sekelilingnya. Jika kelembaban ruang lebih tinggi, produk akan menyerap air, dan bila kelembaban ruang penyimpanan rendah produk akan menguapkan airnya (Syarief dan Halid, 1980).

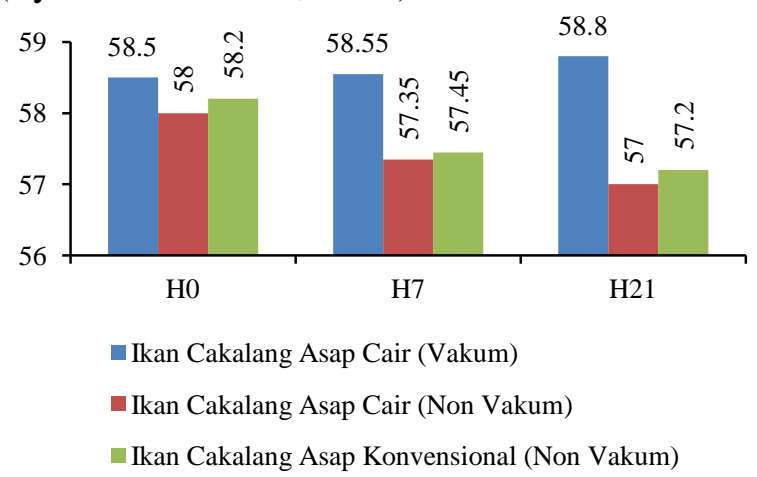

Gambar 1. Nilai kadar air ikan Cakalang (Katsuwonus pelamis L.) asap cair dan ikan cakalang asap konvensional selama 0,7 dan 21 hari penyimpanan pada suhu $\pm 5^{\circ} \mathrm{C}$.

Nilai Standar kadar air ikan asap berdasarkan SNI (2013) adalah maksimal 60-65\%. Hasil penelitian menunjukkan produk ikan asap yang dikemas vakum dan non vakum selama penyimpanan 21 hari memiliki kadar air masih batas standar yang telah ditentukan oleh SNI (2013).

Kadar air merupakan parameter yang penting untuk menentukan kualitas ikan asap yang dihasilkan. Kadar air yang terkandung di dalam ikan asap dapat mempengaruhi daya simpan ikan asap. Karena kadar air merupakan media mikroba untuk berkembang biak (Agus, et al. 2014).

\section{Penentuan Derajat Keasaman (pH)}

Berdasarkan hasil penelitian, diperoleh nilai rata-rata $\mathrm{pH}$ ikan asap cair dan ikan asap konvensional selama penyimpanan pada produk yang dikemas vakum dan non vakum. Nilai rata-rata $\mathrm{pH}$ ikan Cakalang asap cair yang dikemas vakum pada penyimpanan 0 hari 5,67\% dan pada produk yang tidak dikemas vakum adalah $5,77 \%$ sedangkan pada produk ikan cakalang asap konvensional yaitu $5,86 \%$. Pada penyimpanan 7 hari nilai rata-rata $\mathrm{PH}$ pada produk ikan cakalang asap cair yang dikemas vakum adalah $5,78 \%$ dan pada produk yang tidak dikemas vakum 5,79\% sedangkan pada produk ikan asap konvensional non vakum adalah 5,87\%. Pada penyimpanan 21 hari nilai rata-rata $\mathrm{pH}$ ikan cakalang asap cair yang dikemas vakum 5,78\% dan pada produk yang tidak dikemas vakum adalah $5,80 \%$ sedangkan pada produk ikan cakalang asap konvensional adalah 5,88\%. Dari data tersebut dapat dibuat suatu hubungan antara lama penyimpanan terhadap nilai $\mathrm{pH}$ ikan cakalang asap cair yang dikemas vakum dan non vakum dan juga ikan cakalang asap konvensional non vakum.

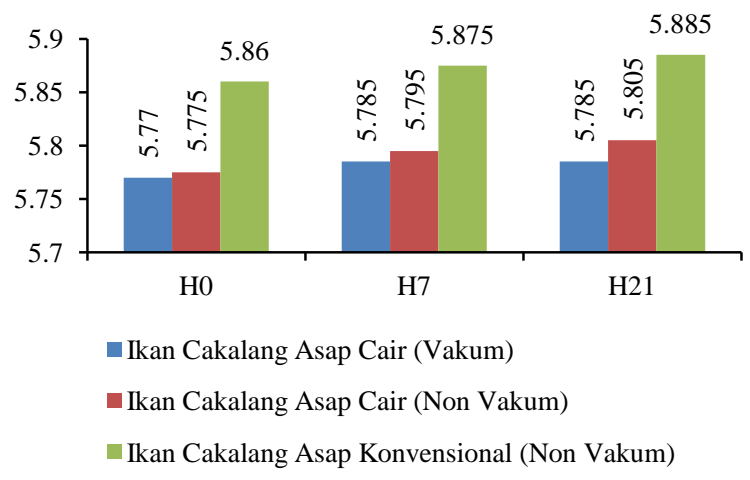

Gambar 2. Nilai pH ikan cakalang (Katsuwonus pelamis L.) asap selama 0,7 dan 21 hari penyimpanan pada suhu $\pm 5^{\circ} \mathrm{C}$.

Dari gambar 2 dapat dilihat bahwa nilai $\mathrm{pH}$ pada produk yang dikemas vakum nilai $\mathrm{pH}$ nya tetap stabil pada $\mathrm{pH}$ 5,7 sampai pada penyimpanan hari ke-21 dibandingkan dengan produk yang tidak dikemas vakum $\mathrm{pH}$-nya lebih cepat mengalami kenaikan pada penyimpanan 7 hari. Selama penyimpanan, dapat dilihat produk yang dikemas vakum maupun yang tidak dikemas vakum tidak terlalu mengalami kenaikan 
pH, Menurut Hadiwiyato (1993) daging ikan yang mempunyai $\mathrm{pH}$ tinggi disebabkan karena timbulnya senyawa-senyawa yang bersifat basa seperti amoniak, trimetilamin, dan senyawa volatile lainnya, yang juga dapat menurunkan nilai organoleptik dari produk. Proses glikolisis, enzim sangat berperan sampai terbentuknya asam laktat. Hal ini menyebabkan akumulasi asam laktat berjalan lebih lambat sehingga penurunan $\mathrm{pH}$ ikan juga berlangsung lebih lambat (Munandar, 2009).

Chamidah (2000) menyatakan bahwa selama penyimpanan terjadi penguraian protein menjadi senyawa basa antara lain amoniak. Nilai $\mathrm{pH}$ bahan pangan selama penyimpanan dapat berubah karena adanya protein yang terurai oleh enzim proteolitik dan bantuan bakteri menjadi asam karboksilat, asam sulfida, amoniak dan jenis asam lainnya. Oleh karena itu nilai $\mathrm{pH}$ ikan cakalang asap yang dihasilkan walaupun meningkat tetapi masih pada kondisi asam. Nilai $\mathrm{pH}$ merupakan salah satu indikator yang digunakan untuk menentukan tingkat kesegaran ikan. Pada proses pembusukan ikan, perubahan $\mathrm{pH}$ daging sangat besar peranannya karena berpengaruh terhadap proses autolysis dan penyerangan bakteri.

Menurut Fardiaz (1982) pH yang baik untuk ikan yang diawetkan antara 2,0-5,5 sedangkan $\mathrm{pH}$ 6,0-8,0 merupakan media yang baik untuk pertumbuhan mikroorganisme. Nilai $\mathrm{pH}$ yang didapat pada penelitian ini pada produk ikan cakalang asap cair yang dikemas vakum dan non vakum dan juga produk ikan cakalang asap konvensional non vakum masih termasuk dalam kriteria mutu yang baik sampai penyimpanan 21 hari.

\section{Total Koloni Kapang}

Kapang termasuk salah satu jenis mikroba yang sering ditemui pada hasil perikanan dan produk olahannya, maka dari itu kapang menjadi salah satu parameter untuk menentukan mutu dari produk olahan perikanan. Berdasarkan koloni kapang pada ikan Cakalang asap cair selama penyimpanan pada produk yang dikemas vakum dan non vakum dan juga pada ikan cakalang asap konvensional dapat dilihat pada tabel 1.

Hasil penelitian tersebut menunjukkan bahwa ikan asap cair yang dikemas vakum memiliki total koloni kapang lebih sedikit dibandingkan dengan total koloni kapang yang ada pada ikan asap cair yang tidak dikemas vakum, hal ini dikarenakan pada pengemasan vakum bakteri pembusuk aerob yang ada akan dihambat oleh kondisi lingkungan anaerob pengemasan vakum. Dengan ketiadaan udara dalam kemasan, maka kerusakan akibat oksidasi dapat dihilangkan sehingga kesegaran produk yang dikemas akan lebih bertahan 3-5 kali lebih lama dibandingkan produk yang dikemas dengan pengemasan non-vakum (Jay 1996).

Tabel 1. Total Koloni Yang Terdapat Pada Sampel Ikan Cakalang Yang Diteliti.

\begin{tabular}{lcc}
\hline $\begin{array}{c}\text { Sampel Ikan } \\
\text { Cakalang Asap }\end{array}$ & $\begin{array}{c}\text { Lama } \\
\text { penyimpanan }\end{array}$ & $\begin{array}{c}\text { Total koloni } \\
\text { Kapang }(\text { CFU/gr) }\end{array}$ \\
\hline Cair & $\mathbf{H}_{\mathbf{0}}$ & $1,2 \times 10^{2}$ \\
(Vakum) & $\mathbf{H}_{7}$ & $1,3 \times 10^{3}$ \\
& $\mathbf{H}_{21}$ & $3,1 \times 10^{3}$ \\
\hline Cair & $\mathbf{H}_{\mathbf{0}}$ & $1,2 \times 10^{3}$ \\
(Non Vakum) & $\mathbf{H}_{7}$ & $1,2 \times 10^{3}$ \\
& $\mathbf{H}_{\mathbf{2 1}}$ & $3,9 \times 10^{3}$ \\
\hline Konvensional & $\mathbf{H}_{\mathbf{0}}$ & $<10$ \\
(Non Vakum) & $\mathbf{H}_{7}$ & $5,5 \times 10^{1}$ \\
& $\mathbf{H}_{21}$ & $3,2 \times 10^{3}$ \\
\hline
\end{tabular}

Dari hasil penelitian, perbandingan antara jumlah koloni kapang dari ikan cakalang asap cair dan ikan cakalang asap konvensional menunjukkan bahwa total koloni kapang dari kedua produk tersebut tidak berbeda jauh, kemudian pada penyimpanan 0 hari ikan cakalang asap konvensional total koloni kapangnya $<10$ dan total koloni kapang dari ikan asap cair tidak vakum yaitu $1,2 \times 10^{3}$, hal ini dikarenakan kemungkinan produk ikan asap konvensional telah ditambah dengan bahan pengawet makanan yang tidak aman bagi para konsumen. Menurut Fardiaz (1992), beberapa kapang mengeluarkan komponen yang dapat menghambat pertumbuhan organisme lainnya. Komponen ini disebut antibiotik, misalnya penisilin yang diproduksi oleh Penicillium chrysogenum, dan clavasin yang diproduksi oleh Aspergillus clavatus. Sebaliknya, beberapa komponen lain bersifat mikostatik atau fungistatik, yaitu menghambat pertumbuhan kapang, misalnya asam sorbat, propionat dan asetat, atau bersifat fungisidal yaitu membunuh kapang, sedangkan pada ikan cakalang asap cair menggunakan bahan pengawet yang aman seperti asap cair. Yulstiani (2008), melaporkan bahwa asap cair tempurung kelapa pada konsentrasi 0,6-1,0 \% memiliki kemampuan menghambat pertumbuhan kapang. Sedangkan Zigori dan Parmeter (1984), menyatakan bahwa kondensat asap hasil pembakaran kayu ampu membunuh spora Aspergilus sp, Penicillium sp, dan Mucor sp. Selanjutnya dinyatakan pula 
bahwa penambahan senyawa fenolik di atas $0,25 \%$ meningkatkan sifat fungisida dari asap. Senyawa fenol dalam asap memiliki pengaruh fungisida pada beberapa jamur dan oksidase polifenol berperan dalam metabolisme senyawa fenol dalam asap (Gilbert dan Knowles, 1975).

\section{KESIMPULAN DAN SARAN}

\section{Kesimpulan}

Berdasarkan hasil penelitian yang dilakukan, maka dapat ditarik kesimpulan sebagai berikut:

1. Berdasarkan hasil uji nilai $\mathrm{pH}$ dan air, ikan cakalang (Katsuwonus pelamis L) asap cair yang disimpan dengan pengemas vakum dan non vakum masih baik sampai pada 21 hari penyimpanan. Masih dalam kriteria mutu yang baik menurut SNI (Standar Nasional Indonesia).

2. Dari Hasil uji nilai kadar air, ikan cakalang (Katsuwonus pelamis L) asap cair yang dikemas vakum dan non vakum masih termasuk dalam kriteria mutu yang baik sampai 21 hari penyimpanan, masih dalam kriteria mutu yang baik menurut SNI (Standar Nasional Indonesia).

3. Berdasarkan hasil uji nilai total koloni kapang, ikan cakalang (Katsuwonus pelamis L) asap cair yang dikemas vakum dan non vakum masih termasuk dalam kriteria mutu yang baik sampai 21 hari penyimpanan, Masih dalam kriteria mutu yang baik menurut SNI (Standar Nasional Indonesia).

4. Produk ikan cakalang asap dikemas vakum penyimpanan dingin memiliki mutu yang lebih baik, daya tahan produk dipertahankan dalam jangka yang lebih lama dibanding ikan yang tidak dikemas vakum.

\section{Saran}

Perlu adanya penelitian lanjutan tentang pengaplikasian konsentrasi asap cair yang berbeda pada ikan cakalang asap terhadap mutu dari ikan cakalang asap cair yang dikemas vakum dan non vakum yang disimpan pada suhu dingin.

\section{DAFTAR PUSTAKA}

Adawyah, Rabiatul. 2007. Pengolahan dan Pengawetan Ikan. Bumi Aksara. Jakarta.

Agus. T.S.W., F. Swastawati, da A.P. Anggo. 2014. Kualitas Ikan Pari (Dasyatis sp) Asap Yang Diolah Dengan Ketinggian Tungku Dan Suhu Yang Berbeda.
Jurnal Pengolahan dan Bioteknologi Hasil Perikanan, vol 3. No.1 hal 147-156.

Ali, A., 2005. Mikrobiologi Dasar Jilid I. State University of Makassar Press. Makassar.

AOAC., 1995. Official Methods of Analysis of the Association of Official Analyticial. Chemists. Washington.

Buckle, K.A., R.A. Edwards., G.A. Fleet., and M. Wooton. (1987). Food science. Universitas Indonesia. (Penerjemah: Hari Purnomo dan Adiono, Judul: Ilmu Pangan).

Charles. 2004. The End of the Line: How overfishing is changing the world and what we eat. Ebury Press, London. ISBN 0-09-189780-7.

Fardiaz, S., 1992. Mikrobiologi Pangan I. Penerbit Gramedia Pustaka Utama. Jakarta

Fardiaz, S., 1993. Analisis Mikrobiologi Pangan. PT. Raja Grasida Persada Utama. Jakarta.

Gitrix M. (2007). Kekayaan Laut Indonesia. hal. 3-5. Jakarta: Sekretariat Dewan Maritim IndonesiaDepartemen Kelautan dan Perikanan.

Gilbert J., M.E. Knowles., 1975. The Cmeistry of Smoked food a Riview. J. Food Technol. 10. 245-261.

Hadiwiyoto S, Darmadji P, Purwasari SR. 2000. Pendinginan Pengasapaan Panas Dan Penggunaan Asap Cair Pada Pengolahan Ikan; Tinjauan Kandungan Benzopiren, Fenol, Dan Sifat Organoleptik Ikan Asap. Agritech 20: 14-19.

Haras A, 2004. Pengaruh Konsentrasi Asap Cair Dan Lama Perendaman Terhadap Mutu Fillet Cakalang (Katsuwonus Pelamis) Asap Yang Disimpan Pada Suhu Kamar [skripsi]. Bogor: Fakultas Perikanan Dan Ilmu Kelautan, Institut Pertanian Bogor.

Juniarto. 2003. Teknik Penanganan Ikan. Penebar Swadaya. Jakarta.

Hadiwiyoto, S. 1993. Teknologi Pengolahan Hasil Perikanan. Jilid I. Penerbit Liberty. Yogyakarta.

Juniarto. 2003. Teknik Penanganan Ikan. Penebar Swadaya. Jakarta.

Murniyati, A. S dan Sunarman. 2000. Pendinginan, Pembekuan dan Pengawetan Ikan. Penerbit Kanisius. Yogyakarta.

Martines O, Salmero J, Guillen MD, Casa C. 2007. Textural And Physicochemical Changes In Salmon (Samo salar) Treated With Commercial Liquid Smoke Flavourings. Food Chem 100: 498-503.

Pelczar, M.J dan E.C.S. Chan., 1986. Dasar-dasar Mikrobiologi I. Diterjemahkan oleh Hadioetomo, dkk. Universitas Indonesia Press. Jakarta.

Ray, 2004. Fundamental Food Mikrobiology. CRC. Presss: Boca Raton. 493 h.

Soldera S, Sebastianutto N, Bortolomeazzi R. 2008. Composition Of Phenolic Compounds And Antioxidant Activity Of Commercial Aqueous Smoke Flavorings. J Agric Food Chem 56: 2727-2734.

(SNI) Standard Nasional Indonesia. 2013. Ikan Asap Bagian 1. Spesifikasi. SNI 27 25.1:2013. Badan Standardisasi Nasional. Jakarta.

Soepandi, T. Dan Wardah. 2013. Mikrobiologi Pangan. Teori dan Praktek. Andy Yogyakarta. 493 h. 
Suwetja, I.K. 2011. Biokimia Hasil Perikanan, buku. Diterbitkan Oleh Media Prima Aksara. Jakarta. 204h.

Tranggono dan Sutardi. 1990. Biokimia dan Teknologi Pasca Panen. Universitas Gadjah Mada. Yogyakarta.

Winarno, F.G. 1997. Kimia Pangan dan Gizi. Gramedia. Jakarta.
Yulistiani R., 2008. Asap cair sebagai Bahan Pengawet alami pada Produk daging dan Ikan.

Zagory, D. and J.R. Parmeter. 1984. Fungitoxity of Smoke. Special Topics. The American Phytophatological Society. Vol 74. No 9. Pp 10271031. 